\title{
Risk factors for infection in external ventricular drains
}

\author{
Audrey Beatriz Santos Araujo', Sebastião Gusmão², Marcelo Magaldi², \\ Alander Sobreira Vanderlei ${ }^{3}$, Marina Brugnolli Ribeiro Cambraia ${ }^{3}$
}

Department of Surgery, Federal University of Minas Gerais and Hospital Odilon Behrens, Belo Horizonte, MG, Brazil.

\section{ABSTRACT}

Objective: The present study aims to define the main risk factors for infection in EVD implants performed in a public tertiary hospital in Belo Horizonte, Brazil. Method: The present study performed a retrospective review of 137 cases of EVD implants in 107 patients from January 2006 to December 2008. Of these cases, 25 patients had to be re-operated, totally 141 implanted shunts. Results: Forty-eight (45\%) patients were male and 59 (55\%) were female. The age ranged from 6 to 86 years of age $(52.12 \pm 15.51$ years). The incidence of EVD-related infection was $32.7 \%$, while the device permanence varied from 2 to 54 days (mean of 10 days). The EVDs that were maintained for more than 9.5 days, as well as the device changes proved to be statistically significant factors for cerebrospinal fluid (CSF) infection ( $p<$ $0.001)$. Antibiotic prophylaxis did not change the infection rate $(p=0.395)$. Conclusions: Risk factors for EVD infection included a continuing EVD permanence that lasted for more than 9.5 days and device changes. The present study concluded that there is no advantage for antibiotic prophylaxis regarding CSF infection with EVD implants.

\section{KEYWORDS}

Infection, cerebral ventriculitis, risk factors, antibiotic prophylaxis, hydrocephalus.

\section{RESUMO}

Fatores de risco para infecção em derivações ventriculares externas

Objetivo: Este estudo objetiva avaliar os fatores de risco para infecção em pacientes submetidos a derivações externas em um hospital público terciário de Belo Horizonte. Método: Revisados retrospectivamente 137 prontuários e selecionados 107 pacientes, dos quais 25 foram submetidos a mais de uma DVE, totalizando 141 DVE instaladas no período de janeiro de 2006 a dezembro de 2008. Resultados: Dos 107 pacientes selecionados, 48 (45\%) eram do gênero masculino e 59 (55\%), do feminino. A idade variou de 6 a 86 anos (média de 52,12 e desvio-padrão de 15,51 anos). Ocorreu infecção em $32,7 \%$ dos pacientes (24,8\% das DVE - 35 casos). O número total de dias de DVE variou de 2 a 54 (média de 10 dias) e demonstrou-se que o uso por período maior que 9,5 dias e a troca do sistema apresentaram significância estatística para o desenvolvimento de infecção $(p<0,001)$. 0 uso de antibióticos não apresentou efeito protetor $(p=0,395)$. Conclusões: $A$ troca do sistema e o tempo de permanência da DVE determinaram a ocorrência de infecções, com aumento do risco após o $10^{\circ}$ dia de uso e nos pacientes submetidos a duas ou mais DVE. O uso de antibióticos profiláticos não foi significativo para redução de infecção.

\section{PALAVRAS-CHAVE}

Infecção, ventriculite cerebral, fatores de risco, antibioticoprofilaxia, hidrocefalia.

1 MD, medical assistant, Department of Neurosurgery, Hospital Odilon Behrens, Belo Horizonte, MG, Brazil.

2 MD, medical assistant, Department of Surgery, Federal University of Minas Gerais (UFMG), Belo Horizonte, MG, Brazil.

3 MD, medical resident, Department of Surgery, UFMG, Belo Horizonte, MG, Brazil. 


\section{Introduction}

External ventricular drains (EVDs) are life-saving procedures, frequently used to treat acute hydrocephalus due to intracranial hemorrhage, traumatic brain injury, infections or tumors. ${ }^{1-7}$ The installation technique is quite simple, it is affordable for most health systems, and it represents the best option to monitor intracranial pressure (ICP). In addition, EVDs allow for cerebrospinal fluid (CSF) drainage, aiding in the control of intracranial hypertension (ICH)., ${ }^{3,5-10}$

One of EVD's main complications is the CSF infection, which can lead to prolonged hospitalization due to antibiotic administration, repeated surgeries, and increased morbidity. ${ }^{2,3,5-7,11-14}$ All these factors increase health care costs. ${ }^{15}$ Ratilal et al. ${ }^{16}$ have described that infection results in elevated mortality, seizure disorders and decreased intellectual performance after recovery. The overall infection rate commonly ranges from $0 \%$ to $45 \%$ with a mean of $10 \%$ to $17 \% .3,4,6,7,9,11-13,15,16,18-20$

Several factors have proven to lead to EVD infection, the most reported of which is the amount of time that the draining device remains in the patient. ${ }^{5,13,15}$ Other contributing factors include the frequency with which the device is changed, the lenght of subcutaneous device traject, associated hemorrhage, skull fracture with CSF leak, and sistemic infections. ${ }^{3,5-7,14,18,21,22}$ To the best of our knowledge, only two others reports of EVD risk factors are currently available in Latin American medical data. ${ }^{23,24}$

Therefore the present work aimed to report the EVD infection rates as well as identify the risk factors related to EVD procedures within a Brazilian hospital.

\section{Methods}

All patients had previously received an EVD implant at the Odilon Behrens Hospital in Belo Horizonte, from January 2006 to December 2008, and their medical records were reviewed. A total of 137 charts were analyzed, with 107 patients selected for this study. Twenty-five patients underwent more than one surgical procedure to replace the EVD implant, totaling 141 EVD shunts. Thirty patients were excluded (47 EVDs) due to infections diagnosed prior to the EVD implant (ventriculitis or systemic infection), children of less than 2 years of age, previous antibiotic usage, death, or hospital transfer less than 24 hours after hospitalization and surgery. All EVDs were implanted in an operating room, none of them were installed in the intensive care unit. No EVD implanted with antibiotics or silver impregnated devices were used. During the three years of study, the only EVD catheter used was the Codman EVD system.
In 68 patients one dose of Cephalotin was prescribed 30 minutes before EVD implantation, while 39 patients received no antibiotic prophylaxis.

In the presence of systemic infectious clinical signs (fever, meningism, obnubilation) and CSF analysis with infectious evidence (more than 15 cels $/ \mathrm{mm}^{3}$, elevated CSF protein, and low glucose), the ventriculitis diagnosis was made and therapeutic antibiotics were administered.

The patient data register consisted of patient name, hospital chart number, age, birth date, medical records of the cause of hydrocephalus, date of EVD implant, antibiotic prophylaxis, EVD exchanges, amount of time the EVD was maintained within the patient, previous systemic diseases, systemic infections, signs and symptons of infections, follow up, and discharge date.

The Fisher's and Chi-square tests were used in the statistical analysis to determine the categorical variables, whereas the Student's t test was used to compare the averages, using the SPSS 17.0 program. This study presents no conflicts of interest and has been approved by the ethics committee of Odilon Behrens Hospital.

From the total sample of 107 patients, 48 were male (45\%) and 59 female (55\%). The ages varied from 6 to 86 years, with a mean of 52.12 years (standard deviation of 15.51). Four patients were under 12 years of age.

Twenty-five cases (23.4\%) required EVD revision/ reinsertion, due to the prolonged amount of time that the device remained implanted within the patient (more than 15 days), device dysfunction, or system breakdown. The number of EVD changes varied from 1 to 3 , the majority of which changed only once (17 of 25 total changes).

\section{Results}

A total of 107 patients, who had undergone 124 EVD procedures were included in the analysis. Overall infection was reported in 35 cases, with an infection incidence of $32.7 \%$ and $24.8 \%$ per procedure. Prophylactic antibiotic usage offered no protection from infection. Of the 68 patients $(63.4 \%)$ who received the antibiotic prophylaxis, 20 were diagnosed with ventriculitis (29.4\%). By contrast, of the 39 patients (36.4\%) who received no antibiotic prophylaxis, 15 were diagnosed with ventriculitis $(38,4 \%)$, at a significance level of $p=$ 0.394 . The prophylaxis consisted of one dose of Cephalotin prescribed 30 minutes before implantation.

The main hydrocephalus cause was hemorrhage (Table 1), with 47 patients (43.9\%) presenting subarachnoid hemorrhage upon hospitalization and 36 (33.6\%) presenting hypertensive brain hemorrhage with 
ventricular hematoma. Other causes included tumors, neurocysticercosis, and cerebellar hemorrhage found in a total of 24 patients (22.4\%). However, hydrocephalus cause proved not be significant enough to cause infection $(\mathrm{p}=0.095)$.

\begin{tabular}{lcc}
\hline \multicolumn{3}{c}{$\begin{array}{c}\text { Table } 1 \text { - Hydrocephalus causes in } \\
\text { at Odilon }\end{array}$ Behrens } \\
hospital from & EV po6 to 2008 \\
\hline Etiology & Patient numbers & $\%$ \\
\hline $\begin{array}{l}\text { Subarachnoid } \\
\text { hemorrhage }\end{array}$ & 47 & 43.9 \\
$\begin{array}{l}\text { Supratentorial } \\
\text { hemorrhagic stroke }\end{array}$ & 36 & 33.6 \\
Infratentorial stroke & 10 & \\
Tumor & 9 & 9.3 \\
Neurocysticercosis & 2 & 8.4 \\
Others & 3 & 2.0 \\
Total & 107 & 2.8 \\
\hline
\end{tabular}

Intraventricular bleeding was present in 82 patients, but proved not be significant enough to cause infection $(\mathrm{p}=0.257)$.

The presence of associated diseases were also not significant enough to cause infection $(p=0.459)$, of which, hypertension proved to be the most frequent, whether alone or in association with other diseases, such as diabetes.

Other infection complications could also be observed, the most important of which was pneumonia, which was identified in 37 of the cases.

The length of stay in the hospital after the first EVD varied from 1 to 104 days (mean of $31.1 \pm 19.8$ days in EVD patients that were infected and $12.9 \pm 17.3$ in patients without EVD infection complications).

The amount of time in which the EVD remained implanted within the patient varied from 1 to 54 days (mean of 10 days), and proved to be significant in shunt infections, presenting an increased risk after the $10^{\text {th }}$ day of EVD implant $(\mathrm{p}<0.001)$ (Figure 1).

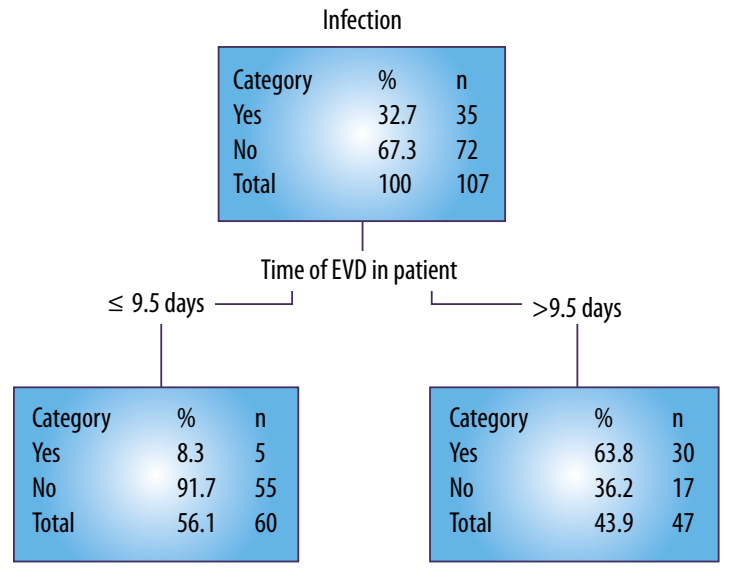

Figure 1 - CART tree to time of EVD use and infection.
EVD exchanges, as well as the frequency of exchange, were statistically significant in contracting ventriculitis ( $\mathrm{p}<0.001)$, as can be seen in table 2. Infection complications were strongly associated with new surgical procedures, and could be identified in all patients who had undergone two or more EVD exchanges.

\section{Discussion}

Despite the technical simplicity of the implant, EVD surgery does present some risks, including bleeding along the catheter path, dislodging from the ventricle, and the system's overall dysfunction may require a replacement of the shunt or a reoperation $(5,6 \%$ of cases). ${ }^{22}$ Infections (ventriculitis or meningitis) are frequent causes of complication, reported in 0 to $45 \%$ of the procedures, depending on the surgical technique used. ${ }^{3,4,6,7,9,11-13,15,16,18-20}$

The most frequent hypothesis related to CSF infection is surgical installation contamination, or posterior contamination, with a retrograde migration of infectious agents into the catheter. Previous (pre-operative) infection of the central nervous system is also another reported cause. ${ }^{3,5,6,9,22,25}$ Previous studies have shown a wide range of definitions and methodologies concerning both EVD-related infections and this difficult comparative analysis. ${ }^{23,25}$

In 1984, Mayhall et al. ${ }^{15}$ published a prospective study with 172 consecutive patients who had undergone 213 ventriculostomies, in which infection rates of $11 \%$, and a time period in which the ventricular catheter was maintained in the patient of more than 5 days were both described as risk factors for infection. These authors suggested that the device should be removed and be replaced by a new implant after this time period, when needed. Paramore and Turner retrospectively analyzed 161 patients who had undergone 253 EVD implants and reported an infection rate of $4 \%$. After six days with the device is in the patient, the infection rate increased to $10.3 \%{ }^{22}$ In 2000 , Alleyne $\mathrm{et} \mathrm{al} .{ }^{26}$ analyzed 308 patients who had EVD implants for 3 or more days and reported ventriculitis in $3.9 \%$ of the cases, with no risk factors found in their analyzes. Their conclusion was that the antibiotics did not in fact reduce the rate of ventriculitis and could potentially select resistent microrganisms.

Lyke et al. ${ }^{6}$ performed a prospective study with 157 adult neurosurgical patients, detecting 11 infections (5.6\%) and reported the amount of time the EVD was maintained within the patient (8.5 days for infection as compared to 5.1 days for non-infected patients, $\mathrm{p}=$ $0.007)$ and CSF drainage out of the catheter $(\mathrm{p}=0.003)$ as risk factors. 


\begin{tabular}{|c|c|c|c|}
\hline \multicolumn{4}{|c|}{$\begin{array}{c}\text { Table } 2 \text { - Analysis of risk factors for infection in EVD procedures at Odilon Behrens } \\
\text { Hospital, Belo Horizonte, Minas Gerais, Brazil, from } 2006 \text { to } 2008\end{array}$} \\
\hline Variables & $\begin{array}{c}\text { Non-infected } \\
\text { patients }(n=72)\end{array}$ & Infected patients $(n=35)$ & $p$ value \\
\hline Male & 32 & 16 & 0.532 \\
\hline Female & 40 & 19 & \\
\hline Mean age (standard deviation), years & $52.85(15.88)$ & $50.63(14.83)$ & 0.490 \\
\hline \multicolumn{4}{|l|}{ Hydrocephalus cause } \\
\hline Subarachnoid hemorrhage & 35 & 11 & \\
\hline Supratentorial hemorrhagic stroke & 22 & 14 & \\
\hline Infratentorial stroke & 7 & 4 & 0.095 \\
\hline Tumor & 6 & 3 & \\
\hline Neurocysticercosis & 0 & 2 & \\
\hline Others & 2 & 1 & \\
\hline \multicolumn{4}{|l|}{ Intaventricular bleeding } \\
\hline Yes & 57 & 25 & 0.257 \\
\hline No & 15 & 10 & \\
\hline \multicolumn{4}{|l|}{ Associated diseases } \\
\hline Yes & 45 & 23 & 0.459 \\
\hline No & 27 & 12 & \\
\hline Time of EVD in patients, days & $7.2 \pm 5.7$ & $17.6 \pm 9.8$ & $<0.0001$ \\
\hline \multicolumn{4}{|l|}{ EVD Exchange } \\
\hline Yes & 7 & 18 & $<0.0001$ \\
\hline No & 65 & 17 & \\
\hline \multicolumn{4}{|l|}{ Number of EVD exchanges } \\
\hline 0 & 65 & 17 & \\
\hline 1 & 7 & 10 & $<0.0001$ \\
\hline 2 & 0 & 1 & \\
\hline 3 & 0 & 1 & \\
\hline \multicolumn{4}{|l|}{ Use of antibiotic prophylaxis } \\
\hline Yes & 24 & 15 & 0.394 \\
\hline No & 48 & 20 & \\
\hline Time of hospitalization, days & $12.9 \pm 17.3$ & $31.1 \pm 19.8$ & \\
\hline \multicolumn{4}{|l|}{ Associated complications } \\
\hline No complications & 38 & 11 & \\
\hline Pneumonia & 12 & 9 & 0.196 \\
\hline Pneumonia + other & 11 & 5 & \\
\hline HE disturbance & 1 & 2 & \\
\hline Others & 10 & 8 & \\
\hline
\end{tabular}

We only find two Brazilian descriptions of EVD risk factors: Larsen studied 110 patients with EVD implants and found an infection rate of $29,09 \%$ and the risk factors were emergency procedures, days in intensive care unit, time of drainage, intracranial bleeding and concurrent infection. ${ }^{24}$ Camacho et al. ${ }^{23}$, reports 119 patients datas (130 EVDs), with an infection rate of $18,3 \%$ (22,4\% per 1000 cateter-day) and the time of drainage was a risk factor for EVD infection.

In a metanalyses that included 17 randomized or almost randomized studies, with 2134 patients, the use of prophylactic antibiotics in EVD was compared with the use of placebos. Ratilal et al. ${ }^{16}$ found no statistically significant difference in the antibiotic-impregnated catheters and the use of no antibiotic-impregnated catheters. The 24-hour prophylactic systemic use of antibiotics demonstrated benefits against infectious complications and they found no relation to age or kind of shunt used. In 2008 Lozier $^{25}$ published a critical review, demonstrating that in retrospective studies the exchange of EVD does not necessarily modify the risk of late infections. 
The literature presents descriptions of successful prophylactic exchanges of EVD external parts (catheters are not exchanged), asseptic, under 48 hours ${ }^{19}$ or of the entire shunt, as a preventive measure within 5 or 6 days after device's implantation. ${ }^{3,15,19}$ However, the literature presents no overall consensus. In fact, many authors are against EVD exchanges for preventive measures. $5,7,9,14,19,21,25,27,28$ Likewise, there is also no evidence that can support the use of antibiotics to reduce infections during ventriculostomies. Moreover, antibiotics have proven to select more resistant agents in ventriculitis. ${ }^{69,226,29}$

Other risk factors of infections stemming from this procedure include age, intraventricular bleeding, opened traumatic lesions, CSF fistulas, and previous neurosurgery. ${ }^{6,7,13-15,20,25}$ The length of the subcutaneous tunnel has also been point out as a predisposing factor. ${ }^{14}$ Khanna et al. ${ }^{2}$ described a new ventriculostomy technique with a subcutaneous tunnel for the ventricular catheter reaching a final point in the inferior thoracic region or superior abdominal region. In 100 consecutive cases, using only perioperative prophylactic antibiotics, these authors found a $4 \%$ infection rate, no infection during the first 16 days of shunt implantation (average of 18.3 days -5 to 40 days) and a ventriculitis incidence of 2.37/1000 shunting days.

Of the patients in the present study, $63.4 \%$ received antibiotic prophylaxis 30 minutes prior to the EVD insertion procedure; however, its use proved not to be significant enough to prevent ventriculitis $(\mathrm{p}=0.394)$. Therefore the use of prophylactic antibiotics to prevent drain-associated infection remains an unresolved issue. ${ }^{17,23}$ No conclusive evidence has been reported that can support the use of prophylactic antibiotics, nor the period of administration. ${ }^{17,26}$ Some studies have suggested that only a peri-procedure antibiotic use would be sufficient enough to prevent infections, whereas others suggest antibiotic use for 24 hours or for prolonged periods of administration. . $13,17,23,25,26,30-32$ Prospective randomized studies are required to define the proper use of antibiotics in EVD procedures.

In the present study, hydrocephalus and intraventricular bleeding were not statistically significant enough to cause infection.

The time of drainage was relevant when demonstrating the occurrence of infection. This study found no difference in CSF drainages from 1 to 10 days; however, an elevated risk of infection after the $10^{\text {th }} \mathrm{EVD}$ day could be observed $(\mathrm{p}<0.001)$.

Another risk factor that could be identified was exchange of shunts, presenting more infections in patients who had undergone new surgical procedures, as well as infections in all cases in which the EVD was exchanged two or more times. This suggests that preventive exchanges should not performed routinely and that the shunt should be discontinued as soon as possible (before the $10^{\text {th }}$ EVD day).

This study detected infection in 35 EVDs, which represents $32.7 \%$ of the patients or $24.8 \%$ of the EVD procedures. This rate is in accordance with rates described in the literature ( 0 to $45 \%$ ). All efforts should be directed toward reducing infection rates as a whole. As such, neurosurgeons should be aware of the risk factors and take measures to avoid them, such as intensifying aseptic techniques, reducing system manipulation, avoiding daily routine CSF collections for routine exams, managing of the shunt only by trained personnel (nurses, neurosurgeons, fellows, ICU doctors); and trying to avoid shunt exchanges or their maintenance for more than 10 days.

In conclusion, the rates of EVD-related infections proved to be high in the studied hospital. Shunt exchanges and the maintenance of the system within the patient represented independent risk factors for ventriculitis, presenting an increased infection risk after 9.5 days of EVD. Thus, it was impossible to prove any reduction in infection risks through the use of prophylactic antibiotics.

\section{References}

1. Friedman WA, Vries JK. Percutaneous tunnel ventriculostomy. Summary of 100 procedures. J Neurosurg. 1980;53(5):662-5.

2. Khanna RK, Rosenblum ML, Rock JP, Malik GM. Prolonged external ventricular drainage with percutaneous long-tunnel ventriculostomies. J Neurosurg. 1995;83(5):791-4.

3. Kim DK, Uttley D, Bell BA, Marsh HT, Moore AJ. Comparison of rates of infection of two methods of emergency ventricular drainage. J Neurol Neurosurg Psychiatry. 1995;58(4):444-6.

4. Korinek AM, Reina M, Boch AL, Rivera AO, De Bels D, Puybasset $L$. Prevention of external ventricular drain: related ventriculitis. Acta Neurochir (Wien). 2005;147(1):39-45.

5. Lo CH, Spelman D, Bailey M, Cooper DJ, Rosenfeld JV, Brecknell JE. External ventricular drain infections are independent of drain duration: an argument against elective revision. J Neurosurg. 2007;106(3):378-83.

6. Lyke KE, Obasanjo OO, Williams MA, O'Brien M, Chotani $\mathrm{R}$, Perl TM. Ventriculitis complicating use of intraventricular catheters in adult neurosurgical patients. Clin Infect Dis. 2001;33(12):2028-33.

7. Spaho N, Camputaro L, Salazar E, Clara L, Almada G, Lizzi $A$, et al. Guias de práctica clínica para el manejo Del drenaje ventricular externo. Rev Argent Neurocir. 2006;20(3):143-6.

8. Drake JM, lantosca MR. Cerebrospinal fluid shunting and management of pediatric hydrocephalus. In: Schmidek $\mathrm{HH}$, Roberts DW, editors. Operative neurosurgical techniques: indications methods, and results. 5th ed. Philadelphia: Elsevier; 2006. p. 487-508.

9. Leverstein-van Hall MA, Hopmans TE, Van der Sprenkel JW, Blok HE, Van der Mark WA, Hanlo PW, et al. A bundle approach to reduce the incidence of external ventricular and lumbar drain-related infections. J Neurosurg. 2010;112(2):345-53. 
10. Youmans JR. Infections of cerebrospinal shunts. In: Youmans JR, editor. Youmans neurological surgery: a comprehensive reference guide to the diagnosis and management of neurosurgical problems. 4th ed. Philadelphia: W.B. Saunders Company; 2006. p. 956.

11. Beer R, Pfausler B, Schmutzhard E. Infectious intracranial complications in the neuro-ICU patient population. Curr Opin Crit Care. 2010;16(2):117-22.

12. Prabhu VC, Kaufman HH, Voelker JL, Aronoff SC, Niewiadomska-Bugaj M, Mascaro S, et al. Prophylactic antibiotics with intracranial pressure monitors and external ventricular drains: a review of the evidence. Surg Neurol. 1999;52(3):226-36.

13. Rebuck JA, Murry KR, Rhoney DH, Michael DB, Coplin WM. Infection related to intracranial pressure monitors in adults: analysis of risk factors and antibiotic prophylaxis. $\mathrm{J}$ Neurol Neurosurg Psychiatry. 2000;69(3):381-4.

14. Wong GK, Poon WW. External ventricular drain infection. J Neurosurg. 2007;107(1):248-9.

15. Mayhall CG, Archer NH, Lamb VA, Spadora AC, Baggett JW, Ward JD, et al. Ventriculostomy-related infections. A prospective epidemiologic study. $\mathrm{N}$ Engl J Med. 1984;310(9):553-9.

16. Ratilal B, Costa J, Sampaio C. Antibiotic prophylaxis for surgical introduction of intracranial ventricular shunts: a systematic review. J Neurosurg Pediatr. 2008;1(1):48-56.

17. McCarthy PJ, Patil S, Conrad SA, Scott LK. International and specialty trends in the use of prophylactic antibiotics to prevent infectious complications after insertion of external ventricular drainage devices. Neurocrit Care. 2010;12(2):220-4.

18. Bogdahn U, Lau W, Hassel W, Gunreben G, Mertens HG, Brawanski A. Continuous-pressure controlled, external ventricular drainage for treatment of acute hydrocephalus-evaluation of risk factors. Neurosurgery. 1992;31(5):898903.

19. Pfisterer W, Mühlbauer M, Czech T, Reinprecht A. Early diagnosis of external ventricular drainage infection: results of a prospective study. J Neurol Neurosurg Psychiatry. 2003;74(7):929-32.

20. Scheithauer S, Bürgel U, Ryang YM, Haase G, Schiefer J, Koch S, et al. Prospective surveillance of drain associated meningitis/ventriculitis in a neurosurgery and neurological intensive care unit. J Neurol Neurosurg Psychiatry. 2009;80(12):1381-5.

21. Holloway KL, Barnes T, Choi S, Bullock R, Marshall LF, Eisenberg HM, et al. Ventriculostomy infections: the effect of monitoring duration and catheter exchange in 584 patients. J Neurosurg. 1996;85(3):419-24.
22. Paramore CG, Turner DA. Relative risks of ventriculostomy infection and morbidity. Acta Neurochir (Wien). 1994;127(12):79-84.

23. Camacho EF, Boszczowski I, Basso M, Jeng BC, Freire MP, Guimarães T, et al. Infection rate and risk factors associated with infections related to external ventricular drain. Infection. 2011;39(1):47-51.

24. Larsen IC. Avaliação dos fatores de risco para infecção liquórica na drenagem ventricular externa [dissertação]. Curitiba: Universidade Federal do Paraná; 2008.

25. Lozier AP, Sciacca RR, Romagnoli MF, Connolly ES Jr. Ventriculostomy-related infections: a critical review of the literature. Neurosurgery. 2008;62(Suppl 2):688-700.

26. Alleyne $\mathrm{CH}$ Jr, Hassan M, Zabramski JM. The efficacy and cost of prophylactic and perioprocedural antibiotics in patients with external ventricular drains. Neurosurgery. 2000;47(5):1124-7.

27. Schultz M, Moore K, Foote AW. Bacterial ventriculitis and duration of ventriculostomy catheter insertion. J Neurosci Nurs. 1993;25(3):158-64.

28. Wong GK, Poon WS, Wai S, Yu LM, Lyon D, Lam JM. Failure of regular external ventricular drain exchange to reduce cerebrospinal fluid infection: result of a randomised controlled trial. J Neurol Neurosurg Psychiatry. 2002;73(6):759-61.

29. Poon WS, Ng S, Wai S. CSF antibiotic prophylaxis for neurosurgical patients with ventriculostomy: a randomised study. Acta Neurochir Suppl. 1998;71:146-8.

30. Lucey MA, Myburgh JA. Antibiotic prophylaxis for external ventricular drains in neurosurgical patients: an audit of compliance with a clinical management protocol. Crit Care Resusc. 2003;5(3):182-5.

31. Sonabend AM, Korenfeld Y, Crisman C, Badjatia N, Mayer SA, Connolly ES Jr. Prevention of ventriculostomy-related infections with prophylactic antibiotics and antibioticcoated external ventricular drains: a systematic review. Neurosurgery. 2011;68(4):996-1005.

32. Wong GK, Poon WS, Lyon D, Wai S. Cefepime vs. ampicillin/ sulbactam and aztreonam as antibiotic prophylaxis in neurosurgical patients with external ventricular drain: result of a prospective randomized controlled clinical trial. J Clin Pharm Ther. 2006;31(3):231-5.

Correspondence address

Audrey Beatriz Santos Araujo

Av. Bernardo Vasconcelos, 2600/304, Ipiranga

31160-440 - Belo Horizonte, MG, Brasil

Telefone: (31) 3344-4838

E-mail: franciscoaudrey@uol.com.br. 